\section{Differences in self-rated health among older adults according to socioeconomic circumstances: the Bambuí Health and Aging Study}

\author{
Diferenças na estrutura da auto-avaliação \\ da saúde em idosos com diferente situação \\ sócio-econômica: Projeto Bambuí
}

Maria Fernanda Lima-Costa 1 Josélia Oliveira Araújo Firmo 1 Elizabeth Uchôa ${ }^{1}$

\footnotetext{
1 Núcleo de Estudos em Saúde Pública e

Envelhecimento, Fundação Oswaldo Cruz/Universidade Federal de Minas Gerais, Belo Horizonte, Brasil.

Correspondence M. F. Lima-Costa Núcleo de Estudos em Saúde Pública e Envelhecimento, Fundação Oswaldo Cruz/Universidade Federal de Minas Gerais. Av. Augusto de Lima 1715, Belo Horizonte, $M G$ 30190-002, Brasil. lima-costa@cpqrr.fiocruz.br
}

\section{Abstract}

Self-rated health is influenced by socioeconomic circumstances, but related differences in its structure have received little attention. The objective of this study was to examine whether self-rated health structure differs according to socioeconomic circumstances in later life. The study included 1,505 individuals (86.4\%) residing in Bambui and aged 60 years or older. Correlates of self-rated health among lower-income older adults (monthly household income $<$ US\$240.00) and higher-income seniors were assessed. Social network stood out as a major factor in the structure of self-rated health among the poorest. Psychological distress was independently associated with worse self-rated health among the poorest, while perceptions by the wealthiest were broader, including psychological distress, insomnia, Trypanosoma cruzi infection, use of medications, and access to health services. Physician visits and hospitalizations were associated with self-rated health in both groups. Our results show important differences in the structure of self-rated health according to socioeconomic circumstances and reinforce the need for policies to reduce health inequalities in later life.

Aging Health; Social Conditions; Diagnosis of Health Situations

\section{Introduction}

Population aging has increased the need to identify health determinants and inequalities in later life 1 . Self-rated health is one of the most commonly used indicators in social epidemiology and geriatric research, because health perception consistently predicts both mortality and functional decline 2 . Furthermore, self-rated health is a better predictor of mortality than objective measurements of health status 2,3 , reflecting an integrated perception by the individual that includes biological, psychosocial, and social dimensions ${ }^{4}$. Self-rated health is heavily influenced by socioeconomic conditions. This association has been amply demonstrated in ecological 5 , cross-sectional 6,7,8, and longitudinal studies 9 . Nevertheless, differences in the structure of self-rated health according to socioeconomic circumstances have received little attention.

As a nation, Brazil displays major social inequalities and in 1998/1999 had the world's second most extreme income concentration 10 . Intense aging of the population has been observed: the number of inhabitants aged $\geq 60$ years increased from 3 million in 1960 to 14 million in 2000 and will reach an estimated 32 million in 2020, representing in absolute terms the

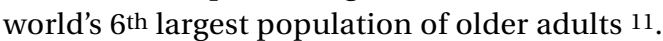
Social inequalities are reflected in the health conditions of the Brazilian elderly 12 . A recent 
study in a small town in Brazil (Bambuí, Minas Gerais State) showed that all health indicators were worse among seniors with the lowest household income, including their self-perceived health. The results of this work were important to show that even relatively small differences in household income were sufficiently sensitive to identify the elderly with the poorest selfrated health 13 . According to a qualitative study among elderly women in this community, evaluation of the severity and relevance of health problems were determined more by the ability to deal with problems than by the problems themselves. This ability was associated with family support and access to medical care, and such access is either facilitated or hindered by socioeconomic circumstances 14 .

Based on the above-mentioned results, we raised the hypothesis that the structure of selfrated health in this community differs between seniors with lower and higher family incomes, and that social network and access to medical care are important factors in such differences. Based on this theoretical background, we used the baseline data from the Bambuí cohort study (BHAS) 15 to assess whether self-rated health differs by socioeconomic circumstances, in relation to five dimensions: (a) socio-demographic, (b) social network, (c) lifestyle risk factors, (d) health status, and (e) access to (and use of) health services.

\section{Methods}

\section{Study area}

Bambuí (15,000 inhabitants) is situated in the State of Minas Gerais, southeast Brazil. The town has one physician per 1,000 inhabitants, a general hospital, and a health clinic, and there are no institutions for the elderly. Life expectancy at the time of the study was 70 years. The leading causes of death among the elderly were stroke, Chagas disease, ischemic heart disease, and chronic obstructive pulmonary disease $($ death rates $=110.0,61.4,42.5$, and 18.9 per 100,000 , respectively). Bambuí was formerly an endemic area for Chagas disease, and transmission of Trypanosoma cruzi infection was interrupted in the 1970s, but mortality from Chagas disease remains high among older inhabitants due to a cohort effect 15,16 .

\section{Study population}

Participants in the BHAS cohort were identified through a complete census in the town, conducted by our team in November and December 1996. All residents $\geq 60$ years as of January 1,1997 , were selected to participate in the baseline cohort study. Of the 1,742 residents in this age group, $92.2 \%$ were interviewed and $85.6 \%$ were examined (blood tests, blood pressure, and anthropometric measurements). Data were collected from January to August 1997. All participants from the baseline cohort were selected for the present study. Further details are described elsewhere 15 .

\section{Interview}

The following variables from the baseline interview were considered in this study: (a) selfrated health; (b) socio-demographic characteristics (age, gender, years of schooling, marital status, generations living in the household, and monthly household income); (c) social network (attendance at a church, clubs, or associations and satisfaction with social network); (d) lifestyle risk factors (smoking, alcohol intake, leisure-time physical activity, and consumption of fruits and vegetables); (e) physical functioning (inability to perform at least one of the following activities of daily living: bathing, dressing, moving from bed to chair, toileting and/or eating); (f) other indicators of health status (psychological distress, insomnia, number of prescription drugs); (h) access to and use of health services (complaints when medical care is required, number of visits to physician, and number of hospital admissions). Further details are described elsewhere 15.

Monthly household income was measured as the number times the prevailing Brazilian minimum wage $(1$ monthly minimum wage $=$ US\$ 120.00) for all members of the household before taxes. Monthly household income (as measured in times the minimum wage) was grouped in tertiles, with the low-income group defined as the lowest tertile $(<2.0$ times the minimum wage).

With respect to mental health, the 12 -item version of the General Health Questionnaire (GHQ) was used to identify psychological distress (depression and/or anxiety) in the previous two weeks. The $\geq 4$ cutoff was used, based on the GHQ scoring method 17. The version used in this study had been previously validated in 
Brazil 18. Insomnia was defined as the presence of any sleep disruption in the last 30 days, at least three times in a week, with whatever level of inconvenience 19 .

Interviews were conducted by members of the community, selected from those with at least eleven complete years of schooling. When the respondent was incapable of answering the interview due to a cognitive deficit or any other health problem, a proxy was used; proxies did not reply to questions that required personal judgment, which included self-rated health. The reliability of the interview was determined by repeating selected questions from the BHAS interview in a random sample of $10.0 \%$ of the participants 15 .

\section{Physical measurements and blood tests}

The following physical measurements and blood tests were considered in this study: blood pressure, waist circumference, blood glucose, triglycerides, HDL cholesterol, and serology for $T$. cruzi. The metabolic syndrome was considered present when the individual presented three out of five conditions with results greater than or equal to the following cutoffs: $130 \mathrm{~mm} / \mathrm{Hg}$ for systolic pressure and $85 \mathrm{~mm} / \mathrm{Hg}$ for diastolic pressure; waist circumference $102 \mathrm{~cm}$ for men and $88 \mathrm{~cm}$ for women; $110 \mathrm{mg} / \mathrm{dl}$ for blood glucose; $150 \mathrm{mg} / \mathrm{dl}$ for triglycerides; and $40 \mathrm{mg} / \mathrm{dl}$ for HDL cholesterol for men and $50 \mathrm{mg} / \mathrm{dl}$ for women 20 . Serology for T. cruzi used indirect hemagglutination (IHA) and enzyme-linked immunosorbent assay (ELISA). Antibodies were considered present when the individual showed positive results for both tests 16 . Blood pressure was measured as previously recommended 21 . Blood tests were performed using blood samples collected after 12 hours' fasting.

\section{Analysis of data}

The characteristics of individuals with worse self-rated health (bad/very bad) were compared to those who rated their health as fair, good, or very good. Crude and adjusted analyses used logistic regression 22. Age and gender were considered a priori as confounding variables in this study and were included in the initial logistic model. All other variables presenting associations with self-rated health at the < 0.20 level in the bivariate analysis were also included in the initial logistic model, and the final model maintained those that remained associated with self-rated health at the $<0.05 \mathrm{lev}$ el. Statistical analyses used the Stata software.

\section{Results}

From a total of 1,606 participants in the baseline cohort, 1,505 participated in this study (90 were excluded because they required a proxy during the interview and 11 were excluded because of missing data on household income). Among participants, 584 (38.8\%) were men and $921(61.2 \%)$ women. Age varied from 60 to 95 years $($ mean $=69.0)$

Self-rated health grouped in three categories as good/very good, fair, or bad/very bad was reported by $373(24.8 \%), 740$ (49.2\%), and 392 (26.1\%) of the participants, respectively. Four hundred and forty-one (29.3\%), 568 (37.7\%), and 406 (33.0\%) individuals reported monthly household income as $<2.0,2.0-3.9$, and $4-7$ times the Brazilian minimum wage, respectively.

Table 1 presents results of the bivariate analysis of associations between self-rated health, socio-demographic characteristics, and social network. Among participants with lower monthly household incomes, less schooling (4-7 years) and satisfaction with social network (unsatisfactory/very unsatisfactory) showed a significant association with self-perception of health. For those with a higher household income, the corresponding associations were age $(\geq 80)$, gender (female), years of schooling (1-3, $4-7$, and $\geq 8$ ), marital status (divorced/separated), attendance at clubs or associations (less than once a month versus at least once a month), and satisfaction with social network (unsatisfactory/very unsatisfactory).

In relation to lifestyle risk factors, among the low-income elderly, only alcohol consumption ( $<5$ times per week) was significantly associated with perception of health. Among the better-off, an association was observed for frequency of exercise during leisure time (less than once a week) (Table 2)

The inability to perform at least one activity of daily living, psychological distress, insomnia, metabolic syndrome, and number of prescription drugs were all significantly associated with level of self-rated health in the bivariate analysis, regardless of family income. Seropositivity for T. cruzi was associated with perception of health only among the better-off (Table 3 ).

All indicators of access to (and use of) health services (complaints when medical care is required, number of visits to physician, and number of hospital admissions) were significantly associated with self-rated health in both socioeconomic groups (Table 4).

After adjusting for confounders, satisfaction with social network (unsatisfactory/very unsatisfactory), psychological distress, number of 
Associations (odds ratios and $95 \% \mathrm{Cl}$ ) between worse self-rated health, socio-demographic characteristics, and social network among older adults with lower and higher monthly household incomes.

The Bambuí Health and Aging Study, Brazil.

\begin{tabular}{|c|c|c|c|c|c|c|}
\hline \multirow[t]{2}{*}{ Characteristics } & \multicolumn{3}{|c|}{$\begin{array}{l}\text { Lower monthly household } \\
\text { income }(<\text { US\$240.00) }\end{array}$} & \multicolumn{3}{|c|}{$\begin{array}{l}\text { Higher monthly household } \\
\text { income ( } \geq \text { US\$240.00) }\end{array}$} \\
\hline & $\mathrm{n}$ & $\%$ & OR $(95 \% \mathrm{Cl})$ & $n$ & $\%$ & OR $(95 \% \mathrm{Cl})$ \\
\hline \multicolumn{7}{|l|}{ Age group (years) } \\
\hline $60-69$ & 240 & 54.4 & 1.00 & 658 & 61.8 & 1.00 \\
\hline 70-79 & 148 & 33.6 & $1.19(0.78-1.83)$ & 307 & 28.9 & $0.93(0.67-1.30)$ \\
\hline$>80$ & 53 & 12.0 & $0.77(0.40-1.49)$ & 99 & 9.3 & $1.61(1.01-2.56)$ \\
\hline \multicolumn{7}{|l|}{ Gender } \\
\hline Males & 145 & 32.9 & 1.00 & 439 & 41.3 & 1.00 \\
\hline Females & 296 & 67.1 & $1.20(0.79-1.83)$ & 625 & 58.7 & $2.02(1.48-2.76)$ \\
\hline \multicolumn{7}{|l|}{ Years of schooling } \\
\hline 0 & 204 & 46.3 & 1.00 & 263 & 24.8 & 1.00 \\
\hline $1-3$ & 138 & 31.3 & $0.72(0.46-1.13)$ & 360 & 34.0 & $0.51(0.35-0.73)$ \\
\hline $4-7$ & 90 & 20.4 & $0.45(0.26-0.80)$ & 324 & 30.6 & $0.49(0.37-0.71)$ \\
\hline$>8$ & 9 & 2.0 & $1.19(0.31-4.56)$ & 113 & 10.7 & $0.28(0.15-0.52)$ \\
\hline \multicolumn{7}{|l|}{ Marital status } \\
\hline Married/live together & 131 & 29.7 & 1.00 & 612 & 57.5 & 1.00 \\
\hline Single & 53 & 12.0 & $0.64(0.32-1.28)$ & 92 & 8.7 & $0.87(0.49-1.52)$ \\
\hline Divorced/separated & 34 & 7.7 & $0.68(0.30-1.53)$ & 44 & 4.1 & $2.18(1.15-4.16)$ \\
\hline Widow & 223 & 50.6 & $0.85(0.55-1.34)$ & 316 & 29.7 & $1.29(0.94-1.78)$ \\
\hline \multicolumn{7}{|l|}{$\begin{array}{l}\text { Number of generations living } \\
\text { in the household }\end{array}$} \\
\hline Live alone & 179 & 40.8 & 1.00 & 64 & 6.0 & 1.00 \\
\hline 1 & 84 & 19.1 & $1.50(0.87-2.58)$ & 237 & 22.3 & $1.30(0.62-2.75)$ \\
\hline 2 & 118 & 26.9 & $1.38(0.84-2.25)$ & 521 & 49.0 & $1.69(0.83-3.41)$ \\
\hline$>3$ & 58 & 13.2 & $1.22(0.65-2.28)$ & 242 & 22.7 & $1.78(0.85-3.71)$ \\
\hline \multicolumn{7}{|l|}{ Church attendance } \\
\hline Less than once a month & 21 & 5.7 & 1.00 & 42 & 3.8 & 1.00 \\
\hline At least once a month & 248 & 66.9 & $154(0.57-4.17)$ & 724 & 64.6 & $0.75(0.16-3.52)$ \\
\hline Once a week or more & 102 & 27.5 & $1.77(0.63-5.00)$ & 354 & 31.6 & $1.18(0.24-5.76)$ \\
\hline \multicolumn{7}{|l|}{$\begin{array}{l}\text { Attendance at clubs } \\
\text { and/or associations }\end{array}$} \\
\hline Never & 378 & 85.9 & 1.00 & 845 & 79.4 & 1.00 \\
\hline Less than once a month & 40 & 9.1 & $0.51(0.24-1.10)$ & 151 & 14.2 & $0.48(0.30-0.79)$ \\
\hline At least once a month & 22 & 5.0 & $0.52(0.19-1.43)$ & 68 & 6.4 & $0.34(0.15-0.76)$ \\
\hline \multicolumn{7}{|l|}{ Satisfaction with social network } \\
\hline Satisfied/very satisfied & 387 & 88.0 & 1.00 & 948 & 89.1 & 1.00 \\
\hline Indifferent & 24 & 5.5 & $1.06(0.44-2.54)$ & 60 & 5.6 & $1.33(0.74-2.41)$ \\
\hline Dissatisfied/very dissatisfied & 29 & 6.6 & $4.03(1.82-8.92)$ & 56 & 5.3 & $2.20(1.25-3.87)$ \\
\hline
\end{tabular}


Associations (odds ratios and $95 \% \mathrm{Cl}$ ) between worse self-rated health and selected lifestyle risk factors among older adults with lower and higher monthly household incomes. The Bambuí Health and Aging Study, Brazil.

\begin{tabular}{|c|c|c|c|c|c|c|}
\hline \multirow[t]{2}{*}{ Characteristics } & \multicolumn{3}{|c|}{$\begin{array}{l}\text { Lower monthly household } \\
\text { income (< US\$240.00) }\end{array}$} & \multicolumn{3}{|c|}{$\begin{array}{l}\text { Higher monthly household } \\
\text { income ( } \geq \text { US\$240.00) }\end{array}$} \\
\hline & $\mathrm{n}$ & $\%$ & OR $(95 \% \mathrm{Cl})$ & $\mathrm{n}$ & $\%$ & OR $(95 \% \mathrm{Cl})$ \\
\hline \multicolumn{7}{|l|}{ Current smoker } \\
\hline No & 350 & 79.4 & 1.00 & 882 & 82.9 & 1.00 \\
\hline Yes & 91 & 20.6 & $1.24(0.77-2.01)$ & 182 & 17.1 & $1.24(0.86-1.80)$ \\
\hline \multicolumn{7}{|c|}{ Alcohol intake (previous 12 months) } \\
\hline None & 366 & 83.0 & 1.00 & 810 & 76.1 & 1.00 \\
\hline$<5$ times per week & 55 & 12.5 & $0.42(0.21-0.85)$ & 184 & 17.3 & $0.29(0.17-0.48)$ \\
\hline 3-5 times per week & 6 & 1.4 & $0.85(0.15-4.68)$ & 22 & 2.1 & $0.44(0.13-1.51)$ \\
\hline Daily/almost daily & 14 & 3.2 & $0.46(0.13-1.68)$ & 48 & 4.5 & $0.48(0.21-1.08)$ \\
\hline \multicolumn{7}{|c|}{$\begin{array}{l}\text { Frequency of leisure-time exercise } \\
\text { (previous } 90 \text { days) }\end{array}$} \\
\hline Less than once a month & 376 & 85.3 & 1.00 & 806 & 75.8 & 1.00 \\
\hline At least once a month & 275 & 6.1 & $0.62(0.26-1.52)$ & 95 & 8.9 & $0.77(0.45-1.30)$ \\
\hline Less than once a week & 38 & 8.6 & $0.64(0.30-1.35)$ & 163 & 15.3 & $0.50(0.32-0.81)$ \\
\hline \multicolumn{7}{|c|}{$\begin{array}{l}\text { Daily consumption of fresh fruits } \\
\text { or vegetables (previous } 12 \text { months) }\end{array}$} \\
\hline No & 271 & 61.5 & 1.00 & 494 & 46.4 & 1.00 \\
\hline Yes & 170 & 38.5 & $0.72(0.48-1.09)$ & 570 & 53.6 & $0.81(0.61-1.08)$ \\
\hline
\end{tabular}

physician visits $(1,2-3$, and $\geq 4$ in the previous 12 months) and number of hospitalizations ( $\geq 2$ in the previous 12 months) remained significantly associated with self-rated health in both socioeconomic groups. Among the better- off, insomnia, seropositivity for $T$. cruzi, number of prescription drugs (1-2, 3-4, and $\geq 5$ in the previous 90 days), and problems when medical care is needed also presented independent associations with poor perception of health (Table 5).

\section{Discussion}

The results of this study showed that self-rated health in both lower and higher-income older adults was based on a triad of social network, health status, and access to/use of health services. However, important differences were observed between socioeconomic circumstances. Satisfaction with social network appeared as a greater factor in health perception among the poor as compared to the better-off. Among the former, worse self-rated health was independently associated with a single health status indicator (psychological distress), while health perception by higher income seniors was broad- er, including four indicators of health status. Finally, an indicator of access to health services (complaints when health services are required) was independently associated with self-rated health among the better-off, but not among the poorer individuals in the study.

There is evidence in Brazil 23 and in other countries 24 that low-income older adults experience more difficulty in access to health services, even when coverage by these services is apparently adequate. Thus, it was surprising that this study showed an association between poor self-rated health and complaints when medical care is required among higher-income elderly and the absence of this association in the lower-income group. One possible explanation for this apparent paradox, as previously outlined 25 , is the tendency of low-income seniors to complain less, while among the betteroff suffering is verbalized more explicitly. Another hypothesis, consistent with the Bambuí qualitative study previously mentioned 14 , is that help from the family or the community (in securing a place on line for medical appointments in the public health service or paying for a private consultation, for example) attenuated the perception of difficulty in obtaining med- 
Associations (odds ratios and $95 \% \mathrm{Cl}$ ) between worse self-rated health and selected indicators of health status among older adults with lower and higher monthly household incomes. The Bambuí Health and Aging Study, Brazil.

\begin{tabular}{|c|c|c|c|c|c|c|}
\hline \multirow[t]{2}{*}{ Characteristics } & \multicolumn{3}{|c|}{$\begin{array}{l}\text { Lower monthly household } \\
\text { income (< US\$240.00) }\end{array}$} & \multicolumn{3}{|c|}{$\begin{array}{l}\text { Higher monthly household } \\
\text { income ( } \geq \text { US\$240.00) }\end{array}$} \\
\hline & $\mathrm{n}$ & $\%$ & OR $(95 \% \mathrm{Cl})$ & $n$ & $\%$ & OR $(95 \% \mathrm{Cl})$ \\
\hline \multicolumn{7}{|c|}{$\begin{array}{l}\text { Inability to perform at least one } \\
\text { activity of daily living* }\end{array}$} \\
\hline No & 400 & 90.7 & 1.00 & 1,002 & 94.2 & 1.00 \\
\hline Yes & 41 & 6.4 & $2.41(1.26-4.60)$ & 62 & 5.8 & $4.37(2.59-7.36)$ \\
\hline \multicolumn{7}{|c|}{$\begin{array}{l}\text { Psychological distress in the previous } \\
2 \text { weeks (General Health } \\
\text { Questionnaire score }>4 \text { ) }\end{array}$} \\
\hline No & 166 & 37.6 & 1.00 & 530 & 49.8 & 1.00 \\
\hline Yes & 275 & 62.4 & $2.51(1.62-3.88)$ & 534 & 50.2 & $4.99(3.57-6.99)$ \\
\hline \multicolumn{7}{|c|}{ Insomnia in the previous 30 days } \\
\hline No & 231 & 52.6 & 1.00 & 686 & 64.5 & 1.00 \\
\hline Yes & 208 & 47.4 & $1.84(1.23-2.74)$ & 377 & 35.5 & $2.98(2.22-4.01)$ \\
\hline \multicolumn{7}{|c|}{ Metabolic syndrome } \\
\hline No & 245 & 60.9 & 1.00 & 554 & 56.1 & 1.00 \\
\hline Yes & 157 & 39.1 & $1.62(1.07-2.47)$ & 434 & 43.9 & $1.45(1.07-1.97)$ \\
\hline \multicolumn{7}{|c|}{ Seropositivity for Trypanosoma cruzi } \\
\hline No & 215 & 52.8 & 1.00 & 664 & 66.6 & 1.00 \\
\hline Yes & 192 & 47.2 & $1.02(0.68-1.54)$ & 333 & 33.4 & $2.18(1.61-2.96)$ \\
\hline \multicolumn{7}{|c|}{$\begin{array}{l}\text { Number of prescription drugs taken } \\
\text { in the previous } 90 \text { days }\end{array}$} \\
\hline None & 89 & 20.4 & 1.00 & 219 & 20.7 & 1.00 \\
\hline $1-2$ & 126 & 28.9 & $1.75(0.87-3.52)$ & 300 & 28.4 & $2.34(1.33-4.13)$ \\
\hline $3-4$ & 125 & 28.7 & $4.07(2.08-7.97)$ & 292 & 27.6 & $3.79(2.19-6.57)$ \\
\hline$>5$ & 96 & 22.0 & $6.33(3.15-12.72)$ & 247 & 23.3 & $6.98(4.04-12.05)$ \\
\hline
\end{tabular}

* Dressing, transferring, bathing, toileting and/or eating.

ical services. The central role that satisfaction with social network plays in the structure of self-rated health among poor older adults reinforces this hypothesis. With respect to indicators of health status, the results suggest that among the poorer, diseases or chronic conditions were perceived as less important than other covariates of self-rated health, such as social network and use of health services.

In general, the results of the present study confirm (in one or both of the socioeconomic groups studied) previous observations of the existence of association between self-rated health and socioeconomic circumstances 5,6,7,8, social network 1 , medical conditions 4,26 , access to health services 27 , and physician visits and hospitalizations 28 . Associations between lifestyle risk factors and self-rated health have been ob- served in some studies 29 , but not in all 30 . In the present study, none of the lifestyle risk factors was independently associated with selfrated health in either group. This result is consistent with the absence of association between self-rated health and the metabolic syndrome observed in this study and with previous observations of the absence of association between self-rated health and coronary risk profile 31 . The absence of association between self-rated health and negative lifestyle habits, as previously emphasized 30 , must be considered in planning and evaluating preventive programs based on behavior changes.

The principal limitation of this study was the cross-sectional nature of the data. The analysis thus reveals association rather than temporal relationships. Cross-sectional studies on old- 
Associations (odds ratios and $95 \% \mathrm{Cl}$ ) between worse self-rated health, complaints when medical care is required, physician visits, and hospital admissions among older adults with lower and higher monthly household incomes. The Bambuí Health and Aging Study, Brazil.

\begin{tabular}{|c|c|c|c|c|c|c|}
\hline \multirow[t]{2}{*}{ Characteristics } & \multicolumn{3}{|c|}{$\begin{array}{l}\text { Lower monthly household } \\
\text { income (< US\$ 240.00) }\end{array}$} & \multicolumn{3}{|c|}{$\begin{array}{l}\text { Higher monthly household } \\
\text { income ( } \geq \text { US\$ 240.00) }\end{array}$} \\
\hline & $\mathrm{n}$ & $\%$ & OR $(95 \% \mathrm{Cl})$ & $\mathrm{n}$ & $\%$ & OR $(95 \% \mathrm{Cl})$ \\
\hline \multicolumn{7}{|l|}{$\begin{array}{l}\text { Complaints when medical care } \\
\text { is required }\end{array}$} \\
\hline Did not report any problem & 107 & 24.3 & 1.00 & 406 & 38.3 & 1.00 \\
\hline $\begin{array}{l}\text { Difficulty in making medical } \\
\text { appointments because of waiting } \\
\text { lines and cost }\end{array}$ & 201 & 45.7 & $1.87(1.10-3.18)$ & 334 & 31.5 & $2.54(1.75-3.67)$ \\
\hline Other problem & 132 & 30.0 & $2.20(1.25-3.88)$ & 319 & 30.1 & $2.47(1.70-3.59)$ \\
\hline \multicolumn{7}{|l|}{$\begin{array}{l}\text { Number of physician visits } \\
\text { in the previous } 12 \text { months }\end{array}$} \\
\hline None & 78 & 17.7 & 1.00 & 219 & 20.6 & 1.00 \\
\hline 1 & 84 & 19.0 & $2.22(0.90-5.49)$ & 224 & 21.0 & $2.53(1.31-4.87)$ \\
\hline $2-3$ & 137 & 31.1 & $4.72(2.10-10.62)$ & 285 & 26.8 & $3.74(2.03-6.91)$ \\
\hline$>4$ & 142 & 32.2 & $10.97(4.92-24.49)$ & 336 & 31.6 & $9.83(5.49-17.63)$ \\
\hline \multicolumn{7}{|l|}{$\begin{array}{l}\text { Number of hospital admissions } \\
\text { in the previous } 12 \text { months }\end{array}$} \\
\hline None & 318 & 72.1 & 1.00 & 865 & 81.3 & 1.00 \\
\hline 1 & 75 & 17.0 & $1.65(0.97-2.79)$ & 150 & 14.1 & $1.80(1.22-2.66)$ \\
\hline$>2$ & 48 & 10.9 & $7.04(3.56-13.92)$ & 49 & 4.6 & $9.84(5.23-18.49)$ \\
\hline
\end{tabular}

er adults are also subject to survival bias, which can lead to underestimation of associations. In relation to other methodological aspects, this study used household income rather than individual income of the elderly as an indicator of socioeconomic status, because in the study community the income of the elderly is complemented by the families whenever possible 14. As an indicator of socioeconomic status, we also chose income (a characteristic which can change during the individual's lifetime) instead of education (which generally does not change after a certain age), because our aim was to investigate the influence of current socioeconomic status on health perception by the elderly. We were particularly interested in the socioeconomic and psychosocial determinants of health perception. However, since health status is an important confounding factor in this association, we used several indicators of physical and mental health status. The study thus took advantage of the wide array of data available in the BHAS cohort 15. Another advantage of this study was its qualitative approach both for the prior identification of correlates to be considered and as an aid in the interpretation of the results.
The results extended beyond those of previous studies by demonstrating that the covariates of self-rated health can differ according to socioeconomic circumstances. Our results reinforce the idea that health perception has a universal character, but that its structure can have context-dependent components. For example, among the poor elderly, dissatisfaction with social network (together with use of health services) occupied a more important place in the structure of self-rated health than did health status itself or difficulties in access to medical care. This association appears to be context-dependent, because it suggests that in the study population, the family and/or community are compensating for deficiencies in public services. There is also a context dependency in the association between worse self-rated health and infection by T. cruzi observed among the better-off elderly, because this infection only exists in the Americas. Finally, the results highlight the need for further investigation of social differences in the structure of self-rated health in developing countries and their consequences for adverse health outcomes, as well as for the development of health policies to reduce health inequalities among older adults. 
Final results of multivariate analysis of factors associated with worse self-rated health among older adults with lower and higher monthly household incomes. The Bambui Health and Aging Study, Brazil.

\begin{tabular}{|c|c|c|}
\hline Characteristics & $\begin{array}{c}\text { Lower monthly household } \\
\text { income }(<\text { US\$240.00) } \\
\text { OR }(95 \% \mathrm{Cl}) \#\end{array}$ & $\begin{array}{c}\text { Higher monthly household } \\
\text { income }(\geq \text { US\$240.00) } \\
\text { OR }(95 \% \text { CI)\#\# }\end{array}$ \\
\hline \multicolumn{3}{|l|}{ Social support } \\
\hline \multicolumn{3}{|l|}{ Satisfaction with social network* } \\
\hline Indifferent & $0.73(0.26-2.04)$ & $0.89(0.44-1.80)$ \\
\hline Dissatisfied/very dissatisfied & $4.06(1.69-9.76)$ & $2.37(1.17-4.80)$ \\
\hline \multicolumn{3}{|l|}{ Health status } \\
\hline $\begin{array}{l}\text { Psychological distress in the previous } 2 \text { weeks } \\
(\text { General Health Questionnaire score }>4)^{\star \star}\end{array}$ & $2.02(1.25-3.26)$ & $2.95(2.00-4.36)$ \\
\hline Insomnia in the previous 30 days $^{\star \star}$ & NS & $1.60(1.12-2.28)$ \\
\hline Seropositivity for Trypanosoma cruzi) ${ }^{\star \star}$ & NS & $1.89(1.33-2.69)$ \\
\hline \multicolumn{3}{|l|}{ Number of prescription drugs used in the past 90 days ${ }^{\star \star \star}$} \\
\hline $1-2$ & NS & $1.56(0.81-2.99)$ \\
\hline $3-4$ & NS & $1.81(0.94-3.49)$ \\
\hline$>5$ & NS & $2.23(1.14-4.36)$ \\
\hline \multicolumn{3}{|l|}{ Access and use of health services } \\
\hline \multicolumn{3}{|l|}{ Problems when seeking medical care $e^{\star \star \star \star}$} \\
\hline $\begin{array}{l}\text { Difficulty in making medical appointments because } \\
\text { of waiting lines and cost }\end{array}$ & NS & $1.60(1.04-2.47)$ \\
\hline Other problem & NS & $1.78(1.15-2.76)$ \\
\hline \multicolumn{3}{|l|}{ Number of physician visits in the previous 12 months ${ }^{\star \star \star}$} \\
\hline 1 & $2.20(0.87-5.61)$ & $2.35(1.12-4.92)$ \\
\hline $2-3$ & $3.94(1.68-9.24)$ & $2.22(1.08-4.59)$ \\
\hline$>4$ & $8.32(3.54-19.53)$ & $4.30(2.08-8.88)$ \\
\hline \multicolumn{3}{|l|}{$\begin{array}{l}\text { Number of hospital admissions the in previous } \\
12 \text { months }{ }^{\star \star \star}\end{array}$} \\
\hline 1 & $0.96(0.53-1.71)$ & $0.98(0.62-1.56)$ \\
\hline$>2$ & $4.02(1.92-8.46)$ & $4.22(2.01-8.89)$ \\
\hline
\end{tabular}

OR (95\% Cl): Odds ratios adjusted by multiple logistic regression for all variables listed in the table.

The earlier models included: age, marital status, church attendance, attendance at clubs and/ or associations, satisfaction with social network, current smoker, alcohol intake in the previous 12 months, frequency of leisure-time exercise in the previous 90 days, daily consumption of fresh fruits or vegetables in the previous 12 months, inability to perform at least one activity of daily living, psychological distress in the previous 2 weeks, insomnia in the previous 30 days, metabolic syndrome, seropositivity for T. cruzi, number of prescription drugs, complaints when medical care is required, number of physician visits in the previous 12 months, and number of hospitalizations in the previous month)

\# 440 individuals participated in the final analysis ( $p$ value goodness-of-fit test $=0.610$ ).

\#\# 987 individuals participated in the final analysis ( $p$ value goodness-of-fit test $=0.987$ )

Non-significant (NS): $p>0.05$.

Reference classes: ${ }^{\star}$ satisfied/very satisfied; ${ }^{* \star}$ no; ${ }^{* \star *}$ none; ${ }^{\star \star \star \star}$ did not report any problem. 


\section{Resumo}

A influência da situação sócio-econômica na estrutura da percepção da saúde dos idosos tem recebido pouca atenção. O objetivo foi verificar se a estrutura da percepção da saúde difere em idosos mais pobres em comparação àqueles com melhor poder aquisitivo (renda mensal familiar < 2 vs. $\geq 2$ salários mínimos). O estudo incluiu 1.505 idosos ( $\geq 60$ anos de idade) residentes na cidade de Bambuí, Minas Gerais, Brasil. A satisfação com a rede social surgiu com maior força na estrutura da percepção da saúde entre os mais pobres. Entre esses, sintomas depressivos e ansiosos estavam associados com a auto-avaliação da saúde, ao passo que os idosos com melhor poder aquisitivo apresentavam uma percepção da saúde mais ampla, que incluía sintomas depressivos e ansiosos, insônia, infecção pelo Trypanossoma cruzi, medicamentos utilizados e acesso aos serviços de saúde. Consultas a médicos e hospitalizações apresentaram-se associadas à auto-avaliação da saúde em ambos os grupos. Estes resultados apontam para importantes diferenças na estrutura da percepção da saúde em idosos com menor ou maior renda familiar e reforçam a necessidade de políticas para reduzir as desigualdades em saúde dessa população.

Saúde do Idoso; Condições Sociais; Diagnóstico da Situação em Saúde

\section{Contributors}

M. F. Lima-Costa coordinated the research and was responsible for the design, data analysis, and drafting of the article. J. O. A. Firmo and E. Uchôa played central roles in the research design, discussion of the results, and critical review leading to the final article.

\section{Acknowledgements}

This study was supported by the Financiadora de Estudos e Projetos (FINEP), Brazil. M. F. Lima-Costa and E. Uchôa are fellows of the Conselho Nacional de Desenvolvimento Científico e Tecnológico (CNPq).

\section{References}

1. Grundy E, Sloggett A. Health inequalities in the older population: the role of personal capital, social resources and socio-economic circumstances. Soc Sci Med 2003; 56:935-47.

2. Idler EL, Benyamini Y. Self-rated health and mortality: a review of twenty-seven community studies. J Health Soc Behav 1997; 38:21-37.

3. Mossey JM, Shapiro E. Self rated health: a predictor of mortality among the elderly. Am J Public Health 1982; 72:800-8.

4. Jylha M, Guralnik JM, Ferrucci L, Jokela J, Heikkinen E. Is self-rated health comparable across cultures and genders? J Gerontol 1998; 39:983-90.

5. Kennedy BP, Kawachi I, Glass R, Prothrow-Stigh D. Income distribution, socioeconomic status, and self-rated health in the United States: multilevel analysis. BMJ 1998; 317:917-21.

6. Bobak M, Pkhart H, Rose R, Hertzman C, Marmot M. Socioeconomic factors, material inequalities, and perceived control of self-rated health: crosssectional data from seven post-communist countries. Soc Sci Med 2000; 51:1343-50.

7. Lindstrom M, Sundquist J, Ostergren P-O. Ethnic differences in self-reported health in Malmö in southern Sweden. J Epidemiol Community Health 2001; 55:97-103.

8. Aberg-Yngwe M, Diderichsen F, Whitehead M, Holland P, Burstrom B. The role of income differences in explaining social inequalities in self-rated health in Sweden and Britain. J Epidemiol Community Health 2001; 55:556-61.

9. Lantz PM, Lynch JM, House JS, Lepkowski JM, Mero RP, Musick MA, et al. Socioeconomic disparities in health change in longitudinal study of US adults: the role of health-risk behaviors. Soc Sci Med 2001; 53:29-40.

10. World Bank. World development report 1998/99. Washington DC: World Bank; 1999.

11. Lima-Costa MF, Veras RP. Aging and public health [Editorial]. Cad Saúde Pública 2003; 19:700-1.

12. Lima-Costa MF, Barreto S, Giatti L, Uchôa E. Desigualdade social e saúde em idosos brasileiros: um estudo baseado na Pesquisa Nacional por Amostras de Domicílio. Cad Saúde Pública 2003; 19:745-57.

13. Lima-Costa MF, Barreto SM, Firmo JOA, Uchôa E. Socioeconomic position and health in a population of Brazilian elderly: The Bambuí Health and Ageing Study (BHAS). Rev Panam Salud Publica 2003; 13:387-94.

14. Uchôa E. Contribuição da antropologia para uma abordagem das questões relativas à saúde do idoso. Cad Saúde Pública 2003; 19:849-53.

15. Lima-Costa MF, Uchôa E, Guerra HL, Firmo JOA, Vidigal PG, Barreto SM. The Bambuí Health and Ageing Study (BHAS): methodological approach and preliminary results of a population-based cohort study of the elderly in Brazil. Rev Saúde Pública 2000; 34:126-35.

16. Lima-Costa MF, Barreto SM, Guerra HL, Firmo JOA, Uchôa E, Vidigal PG. Ageing with Trypanosoma cruzi infection in an area where the transmission has been interrupted: the Bambui Health and Ageing Study (BHAS). Int J Epidemiol 2001; 30:887-93. 
17. Goldberg DP, Hillier VF. A scaled version of the General Health Questionnaire. Psychol Med 1979; 9:139-45.

18. Mari JJ, Williams P. A comparison of the validity of two psychiatric screening questionnaires (GHQ12 and SRQ-20) in Brazil, using Relative Operating Characteristics (ROC) analysis. Psychol Med 1985; 15:651-9.

19. Rocha FL, Uchôa E, Guerra HL, Firmo JOA, Vidigal PG, Lima-Costa MFF. Prevalence of sleep complaints and associated factors in communitydwelling older people in Brazil: The Bambuí Health and Ageing Study (BHAS). Sleep Med 2002; 3:2318.

20. Expert Panel on Detection, Evaluation, and Treatment of High Blood Cholesterol in Adults. Executive Summary of the Third Report of the National Cholesterol Education Program (NCEP) Expert Panel on Detection, Evaluation, and Treatment of High Blood Cholesterol in Adults (Adult Treatment Panel III). JAMA 2001; 285:2486-97.

21. Anonymous. The sixth report of the Joint National Committee on Detection, Evaluation, and Treatment of High Blood Pressure. Arch Intern Med 1997; 157:2413-46.

22. Hosmer DW, Lemenshow S. Applied logistic regression. New York: Johns Wiley \& Sons; 1989.

23. Lima-Costa MFF, Guerra HL, Firmo JOA, Vidigal PG, Uchôa E, Barreto SM. The Bambuí Health and Ageing Study (BHAS): private health plan and medical care utilization by older adults. Cad Saúde Pública 2002; 18:177-86.
24. Gornick ME, Eggers PW, Reilly TW, Mentnech RM, Fitterman LK, Kuckenn LE, et al. Effects of race and income on mortality and use of services among Medicare beneficiaries. N Engl J Med 1996; 335:791-9.

25. Burstrom B, Fredlung P. Self-rated health: is it as good a predictor of subsequent mortality among adults in lower as well as in higher social classes? J Epidemiol Community Health 2001; 55:836-40.

26. Han B. Depressive symptoms and self-rated health in community-dwelling older adults: a longitudinal (JAGS) study. J Am Geriatr Soc 2002; 50:154956.

27. Shi L, Starfield B, Politzer R, Regan J. Primary care, self-rated health, and reduction in social disparities in health. Health Serv Res 2002; 37:529-50.

28. Fernandez-de-la-Hoz K, Leon DA. Self-perceived health status and inequalities in use of health services in Spain. Int J Epidemiol 1996; 25:593-603.

29. Manderbacka K, Lundberg O, Martikainen P. Do risk factors and health behaviours contribute to self-ratings of health? Soc Sci Med 1999; 48:171320.

30. Hillen T, Schaub R, Hiestermann A, Kirschner W, Robra BP. Self-rating of health is associated with stressful life events, social support, and residency in East and West Berlin shortly after the fall of the Wall. J Epidemiol Community Health 2000; 54:57580.

31. Fylkenesnes K, Ferde OH. The Tromsa study: predictors of self-evaluated health - has society adopted the expanded health concept? Soc Sci Med 1991; 32:141-6.

Submitted on 10/May/2004

Final version resubmitted on $07 / \mathrm{Jul} / 2004$

Approved on 13/Jul/2004 